\title{
Management of Privatized Moroccan Enterprises?
}

\author{
Driss Daoui* \\ Cadi University Ayyad Marrakech, IBN Tofail-Kenitra University, Morroco
}

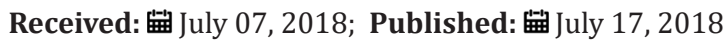

*Corresponding author: Driss Daoui, Cadi University Ayyad Marrakech, IBN Tofail-Kenitra University, Morroco

\begin{abstract}
This article will analyze the impact of the privatization process on the performance of eleven privatized companies through the Moroccan financial market, it concerns an evaluation of the changes in the organization of the latter. The State, by withdrawing its capital from the enterprise, gives the private sector the power to choose the most appropriate modes of governance. Therefore, it is preferable to check that the transfer of ownership as part of the privatization process must be from a bureaucratic managerial system to a market managerial system characterized by its transparency, good productivity and high profitability.
\end{abstract}

Keywords: Governance; Performance; Privatization; Financial Market

\section{Introduction}

Two streams of agency theory have addressed these issues namely: the current of positive agency theory and the classic agentprincipal models. In the end, they resulted in a common result proving the superiority of the performance of private companies. According to the authors of this theory, leaders seek to maximize their own utility more than that of their primary owner; whereas this divergence is very small for private companies.

\section{Analysis of the Performance of Privatized Companies}

Improving the performance of privatized companies is often attributed to the following: first, privatization has been accompanied by a change in leadership. In the same way, the boards of directors have been profoundly modified if only because of the modifications touching on the representation of the State and the employees. Then, the reconfiguration of the shareholding carried out during the privatization leads to quite different structures. The shares of the capital held by the employees, the hard core and the investors redefine the relations with the shareholders. Finally, the increase in the dividend distribution is interpreted as a signal of a reinforcement of the discipline exercised by the shareholders and the possibility of resorting to capital increases, all other things being equal, a relative decrease in the indebtedness. after privatization. This effect should, in fact, be reinforced by the increase in profitability which increases self-financing.

Our article will examine the performance of all listed Moroccan state-owned companies before and after their privatization. This work approach, like the study conducted by Megginson
[1], facilitates the comparison between companies themselves operating in the same sector of activity and having the same size. For that, the best way to obtain convincing results would be the use of an econometric analysis.

\section{Presentation of the Media used}

The use of balance sheets shows an increase in physical assets and financial assets through ratios deemed to be the most reliable and explanatory of the financial situation of privatized firms.

Performance and Profitability Ratios: The most recommended and most reliable ratios are those of profitability. It is a concept also used in the study of Villalonga and DewenterMalatesta (Table 1).

Table 1: Profitability indicators used for governance analysis.

\begin{tabular}{|c|c|}
\hline Title of the Financial & Ratios indicator \\
\hline $\begin{array}{c}\text { Return on equity (ROE: } \\
\text { Return On Equity) }\end{array}$ & $\frac{\text { Résultat Net }}{\text { Capitaux Propres }}$ \\
\hline $\begin{array}{c}\text { Economic profitability (ROA: } \\
\text { Return on Asset) }\end{array}$ & EBIT \\
\hline $\begin{array}{c}\text { The margin of profitability } \\
\text { (ROS: Return on Sales) }\end{array}$ & $\frac{\text { Pésultat Net }}{\text { ventes }}$ \\
\hline The economic result & $\frac{\text { Résultat Net }}{\text { Total Actif }}$ \\
\hline
\end{tabular}

Profitability Indicators used for Governance Analysis: To visualize the impact of these different profitability ratios on the 
performance of companies, we calculated in the average retained before their privatization (from year $\mathrm{N}-3$ to $\mathrm{N}-1$ ) and the average after privatization (of year $\mathrm{N}$ to $\mathrm{N}+\mathrm{n}$ ). According to the results of the table, six companies have a return on equity, a profit margin and a positive economic result. On the other hand, only three companies have satisfactory economic profitability and only four have current earnings on acceptable equity (Table 2).

Table 2: The ROE trend, economic profitability, ROS and ROA.

\begin{tabular}{|c|c|c|c|c|c|c|c|c|}
\hline \multirow{2}{*}{} & \multicolumn{2}{|c|}{ ROE } & \multicolumn{2}{c|}{ Economic Profitability } & \multicolumn{2}{c|}{ ROS } & \multicolumn{2}{c|}{ ROA } \\
\cline { 2 - 8 } & $\begin{array}{c}\text { Moyen. } \\
\text { avant }\end{array}$ & $\begin{array}{c}\text { Moyen. } \\
\text { après }\end{array}$ & Moyen. avant & $\begin{array}{c}\text { Moyen. } \\
\text { après }\end{array}$ & $\begin{array}{c}\text { Moyen. } \\
\text { avant }\end{array}$ & $\begin{array}{c}\text { Moyen. } \\
\text { après }\end{array}$ & $\begin{array}{c}\text { Moyen. } \\
\text { avant }\end{array}$ & $\begin{array}{c}\text { Moyen. } \\
\text { après }\end{array}$ \\
\hline BMCE & $8,36 \%$ & $10,42 \%$ & $4,55 \%$ & $5,55 \%$ & $8,00 \%$ & $19,08 \%$ & $0,68 \%$ & $1,01 \%$ \\
\hline EQDOM & $14,20 \%$ & $18,21 \%$ & $7,10 \%$ & $8,59 \%$ & $16,37 \%$ & $25,22 \%$ & $3,47 \%$ & $4,38 \%$ \\
\hline CTM & $9,46 \%$ & $10,79 \%$ & $14,76 \%$ & $7,61 \%$ & $5,81 \%$ & $8,59 \%$ & $5,42 \%$ & $5,66 \%$ \\
\hline CIOR & $45,29 \%$ & $17,97 \%$ & $22,76 \%$ & $18,09 \%$ & $15,18 \%$ & $14,77 \%$ & $11,29 \%$ & $10,76 \%$ \\
\hline FERTIMA & $15,14 \%$ & $17,54 \%$ & $14,49 \%$ & $20,85 \%$ & $2,66 \%$ & $3,80 \%$ & $3,93 \%$ & $6,31 \%$ \\
\hline GTM & $14,89 \%$ & $68,28 \%$ & $13,96 \%$ & $68,22 \%$ & $4,28 \%$ & $-102,57 \%$ & $6,02 \%$ & $-8,85 \%$ \\
\hline SAMIR & $69,86 \%$ & $35,93 \%$ & $49,17 \%$ & $24,36 \%$ & $7,52 \%$ & $5,30 \%$ & $13,88 \%$ & $12,04 \%$ \\
\hline SMI & $26,25 \%$ & $23,76 \%$ & $30,40 \%$ & $25,46 \%$ & $18,11 \%$ & $25,76 \%$ & $12,19 \%$ & $12,79 \%$ \\
\hline SNI & $19,46 \%$ & $19,77 \%$ & $-0,07 \%$ & $-0,88 \%$ & $827 \%$ & $139661 \%$ & $15,07 \%$ & $17,51 \%$ \\
\hline SOFAC & $18,61 \%$ & $2,53 \%$ & $16,80 \%$ & $7,66 \%$ & $21,19 \%$ & $4,53 \%$ & $3,89 \%$ & $0,77 \%$ \\
\hline SONASID & $40,41 \%$ & $22,00 \%$ & $19,76 \%$ & $25,67 \%$ & $16,51 \%$ & $10,91 \%$ & $20,19 \%$ & $12,81 \%$ \\
\hline
\end{tabular}

According to the results of the table, six companies have a return on equity, a profit margin and a positive economic result. On the other hand, only three companies have satisfactory economic profitability and only four have current earnings on acceptable equity. Regarding the most successful companies after their privatization, EQDOM returns the most its equity capital with an evolution higher than $4 \%$ (14.21 to 18.20). The company with the best economic profitability is FERTIMA with an increase of $4.5 \%$. Profitability margin goes to BMCE Bank with more than $11 \%$. The SNI realizes the most interesting net result compared to its total assets with an increase of nearly $2.5 \%$. The most disadvantaged companies are the oil refinery SAMIR, being the worst-performing firm, which saw the return on its equity decline nearly $-34 \%$, its economic profitability deteriorated by nearly $-25 \%$. The most catastrophic profitability deficit margin goes to the GTM with a decrease of nearly $-107 \%$, while having a least favorable economic result of $-15 \%$.

However according to its ROE, its economic profitability and its current earnings from its equity, GTM belongs indeed to the sample of companies that have achieved a significant increase in the form without being in favor. as powerful. This is due to its negative financial position in the last year before delisting, corresponding to the year 2001, which biased the GTM's calculations and during which its equity, its current result, its EBIT and its result net were negative. Regarding SNI, its profitability margin is certainly interesting, but does not reflect the reality of its performance because its turnover, which is necessary to calculate this ratio, is not a reliable indicator. As mentioned above, the SNI is a holding company that does not have an operating production, which leads it to have a basic turnover and too low. Its main resources come from its financial products made up of the consolidated profits of its subsidiaries.

\section{Financial Ratios for Productivity}

The different ratios we will use will aim to measure efficiency before and after privatization. On this occasion, these productivity indicators will compare the wage bill in relation to: the volume of activity of each company, its capacity for wealth creation, its net profit and its total balance sheet. The indicators used are summarized as follows

\section{Indicators of Effectiveness (Table 3)}

The results of the ratios obtained in the table presented in the appendices show that the SNI holding company presents the most remarkable average growth in terms of a share of the profitability compared to the personnel charge and on the other hand to a decrease in its remuneration. salary compared to the total of its balance sheet. This ratio remains insignificant compared to this firm because it has no productive operation despite the significant increase in its turnover in relation to the said charge. In this context, the EQDOM achieved an increase in this productivity indicator by increasing the volume of its activity from 13 to 15 times its payroll. The BMCE has the best productivity in terms of the decrease of its staff in wealth creation. With respect to the ratios for the most inefficient privatized companies, SONASID and GTM reported a loss of profitability due to high labor costs. The latter also experienced with CIOR a significant decline of almost a third of their activity volume in relation to the number of their workforce. The importance of the payroll is confirmed for this cement company, which unfortunately settles in the first place, having a decrease in its capital intensity. SAMIR occupies the place of the least productive 
company since the part of its added value absorbed by its personnel load has more than tripled from $11 \%$ to more than $39 \%$.

Table 3: Indicators needed for the evaluation of effectiveness.

\begin{tabular}{|c|c|}
\hline Title of the Financial & Ratios Financiers \\
\hline $\begin{array}{c}\text { The wage share in } \\
\text { profitability growth }\end{array}$ & $\frac{\text { RésultatNet }}{\text { ChargePersonnel }}$ \\
\hline $\begin{array}{c}\text { The wage share in the } \\
\text { volume of activity }\end{array}$ & $\frac{\text { Ventes }}{\text { Charge Personnel }}$ \\
\hline Capital intensity & $\frac{\text { TotalActif }}{\text { ChargePersonnel }}$ \\
\hline $\begin{array}{c}\text { The share of employees } \\
\text { in the creation of wealth. }\end{array}$ & $\frac{\text { Charge Personnel }}{\text { Valeur Ajoutée }}$ \\
\hline
\end{tabular}

\section{The use of the Wilcoxon test}

To determine the impact of privatization on other economic performance variables, median-difference tests (Wilcoxon test) [2] will be applied to the averaging series calculated before and after privatization. According to the results obtained, we note that the impact of the privatization process on the performance of privatized public enterprises is very controversial. This is confirmed by the evolution of the averages and medians of some ratios that represent interesting results, while several other indicators lead to mixed and disappointing results.

The most obvious conclusion to draw from the table is that the Wilcoxon test rejects the null hypothesis of no privatization effect for only three ratios: Turnover/Payroll, Debts Financial/CAF and Personnel Expense/Value Added.

\section{Wilcoxon Test Results Analysis [3]}

Regarding the first line of analysis corresponding to the performance evaluation by profitability, the positive trend is for the ROS, whose average growth is increasing, meaning that the net result of the majority of the companies examined has increased compared to that of their sale; however, the median has declined somewhat. The spectacular growth of the average of this result is inflated for that of the SNI holding company for which the turnover does not constitute a reliable element of evaluation of the performance. The second line of analysis relating to financing decisions shows interesting results since the averages of the three ratios relating to the evolution of financial debts are decreasing, which means that the new private governments of privatized companies favor the financing of their activity. using their equity and their cash flow (CAF). The ratio related to the comparison of financial debts with the CAF is significant because it is only increasing for $27 \%$ of firms.

This situation is confirmed by the significant drop, nearly 9 times the average, of the CIF/Investment ratio, which authenticates the recourse to the use of self-financing by seven companies studied out of eleven to realize their strategy of investment. Regarding the third axis related to productivity indicators, we can conclude that the privatization process was not accompanied by a wave of dismissal but by the retention of staff and the hiring of new employees. For this purpose, it should be noted that the most important ratio of this Wilcoxon test study on averages is the ratio between turnover and staff costs. This ratio shows that the evolution of the volume of activity is slower than that of the wage bill resulting in a fall in its average and its median, whereas just $27 \%$ of the establishments were able to raise this indicator following their privatization.

This situation is partly confirmed by the absorption of the personnel burden of a large part of the value added following the increase in the median of the related ratio. The evolution of this ratio is almost $73 \%$ of the companies studied. However, the interesting fall of the average of the said ratio is to be qualified because of the result of the SNI whose added value does not constitute a reliable reference of analysis for reasons which we quoted later. On the other hand, the net result and total assets of most of privatized companies are higher than their personnel costs.

The investment strategy is a favorable axis of analysis for understanding the performance training and expansion policy adopted by the new managers. We note that the increase of investments in terms of turnover is important and concerns more than $81 \%$ of companies. This means that the investment policy is disproportionate since it is only accompanied by a weak growth in the volume of activity. Investment interest in new governance is even reflected in the large number $(72.73 \%)$ of companies that have experienced an increase in their investments relative to the total of their balance sheet due to a rising median but an average overall decline in this financial indicator.

Also, is it worth mentioning an interesting event corresponding to the recourse to external growth by privatized companies since the financial fixed assets are increasing in comparison with the totality of the fixed assets. This may explain the initiative taken by more than half of the new owners of privatized companies seeking to invest in other companies by increasing their equity investments. For the final line of analysis on the distribution of dividends, it undeniably confirms the rule that private property seeks to maximize its profits and dividends. This is explained by the fact that the two ratios relating to the allocation of dividends are growing since they concern nearly 7 out of 11 firms in terms of progression compared to turnover and nearly $55 \%$ of firms when it comes to the distribution of net income. Based on these explanations of the various ratios and as a first glimpse of the results, we conclude that the impact of the privatization process, observed over a period ranging from 6 to 11 years, remains below what the public authorities and investors could hope. This translates into a decrease in the performance indicators corresponding to the profitability and productivity that are necessary to guarantee a good profitability of the shareholders of the company and its durability. 


\section{Dynamic Performance Review}

The aim is to integrate new explanatory indicators corresponding to the environment of the privatization process, the new organizational composition and the profitability mechanisms evaluated by the effects of investment leverage.

\section{Presentation of the Model [4]}

To better analyze the formation of the performance over time of the companies transferred during the period of privatization, we opted for a regression model like the scientific researches of the authors Ehrlich, Villalonga and Alexandre. Thus, to explain the performance variable represented by the variation of the ROA that we have chosen as the most significant and that will be maintained for each company, this regression model will retain 5 variables that we will judge as the most reliable to illustrate the role of the temporal aspect in the formation of the performance. The choice of the dependent variable is since it is less used than the other profitability ratios. The regression model that we adopted is as follows. The first explanatory variable is time-related and represented by " $t$ ", it is calculated from the first year of analysis for 3 years before privatization to the last year of analysis in 2006.

$$
\text { performance }_{i t}=a_{i}+b_{1 i} * t+b_{2 i} * p+b_{3 i} * t p+b_{4} * C A+b_{5} * \text { Cycle }+c_{i t}
$$

The second variable is silent, corresponding to the preprivatization period which takes the value 0 , after privatization, it takes the value " 1 ". This variable is named "p" in relation to the privatization phase. The third variable " $\mathrm{t} * \mathrm{p}$ " consists of the interaction between these two first variables whose references, for each of the companies, will be the variable to explain for the second model [5]. Then, the turnover, presented in the formula by the sign "CA", is the fourth variable retained. It is considered, according to our reasoning, as a relevant variable representing the barometer of the evaluation of the volume of the activity of a privatized company.

The fifth is the last variable in relation to the economic cycle serves as an excellent reference for the representation of the effect of the transferred business environment, namely the variation of gross domestic product designated by the "cycle" during the period before and after privatization that may explain the circumstances leading to this process.

\section{The Results of the Model}

This model is based on an analysis of the pre- and postprivatization period carried out on each company studied to be able to visualize and explain the dynamic effect of the performances realized for each one of them. This applies by observing the results of the t-statistic test of the coefficients of the explanatory variables, the constant and the common variables that will be compared with respect to the ROA economic return variable. To measure the significance of this coefficient t-statistic test, we integrated the rejection test of the null hypothesis of no difference at $1 \%, 5 \%$ and $10 \%$. This allowed us to distinguish the most significant results [6].
It should also be noted that it is necessary to qualify the results obtained from three companies whose regression model did not give good interpretations. It is the company CIOR $\left(\mathrm{R}^{2}=0.28\right.$, adjusted $R^{2}=0.08$, DW $\left.=0.83\right)$, from FERTIMA $\left(R^{2}=0.17\right.$, adjusted $\left.R^{2}=-0.15, D W=1.54\right)$ and from GTM $\left(R^{2}=0.30\right.$, adjusted $R^{2}=-0.50$, $\mathrm{DW}=1.72$ ). Thus, 8 out of 11 privatized companies can be very well explained by the regression model, representing nearly $73 \%$ of the sample.

a) The results for the privatization effect variable " $p$ " reflect static performance information after the privatization period since its dummy value is 1 , whereas before the transfer it was 0 .

b) The variable " $t$ " provides information on economic profitability over all the years analyzed before and after privatization.

c) The variable " $\mathrm{t} * \mathrm{p}$ " rather shows the change in trends in performance analyzed through dynamic efficiency. When a result of this variable is positive, it indicates that performance increases more after privatization than before and vice versa (the negative result means that the performance is decreasing following privatization).

Regarding the diagnosis of the results of privatization variable " $p$ ", it is positive only for 5 companies and negative for the remaining 6 [7]. This diagnosis is not even favorable for half of the firms transferred. In addition, three companies represent positive and significant results while three others are significantly negative.

These results make it possible to confirm those obtained by the Wilcoxon test and that we support the fact that privatization does not make it possible to clearly confirm the achievement of performance, at least from the point of view of the information processed of a static nature [8,9].

\section{Conclusion}

In general, the various situations mentioned above confirm the fact that the privatization process was not a catalytic effect to make the transferred companies profitable for at least the longterm period we analyzed (13 years). In addition, most of privatized companies have a CAF that manages to cover all their investments because the median trend of the ratio is indeed falling but exceeds $148 \%$. This means that the private governance of most privatized firms adequately manages their CAF by finding a satisfactory financial autonomy to minimize their financial dependence vis-àvis credit institutions.

In addition, the investment strategy represents a satisfactory result showing the interest of private governance to invest more to ensure prosperity for its business. This is reflected in the significant increase, in terms of median, of investment compared to the volume of activity, especially during the entire analysis period. M Finally, the positive impact of the privatization process on the transferred 
companies has only been momentarily profitable, in terms of an interesting investment policy, an externality and the adoption of a self-financing strategy. deleveraging more than successful, this without forgetting the leaning of private administrators to the maximization of distribution of dividends.

\section{References}

1. Alexandre h, Charreaux g (2004) The effectiveness of French privatizations: a dynamic vision through the theory of governance. Economic Review 4(55): 467-494.

2. Bancel F (1997) Corporate Governance, Economica.

3. Bellalah M (1998) Comparative Essays on the Governance Systems of Industrialized and Emerging Countries, Discussion Paper, University of Cergy.
4. (1995) Bourgignon "Can we define performance? "In French Journal of Accounting".

5. Causse G (1988) Reforms of public enterprises. Synthesis Document.

6. Charreaux G, Court A, Joffer P (1987) New theories to manage the company, Economica.

7. Megginson WL, AL, Nash RC, Van Randenborgh M (1994) The Financial and Operating Performance of Newly Privatized Firms: An International Empirical Analysis. Journal of Finance 49(2): 403-452.

8. Megginson WL, Netter JM (2001) From State to Market: A Survey of Empirical Studies on Privatization. Journal of Economic Literature 39(2): 88.

9. VOISIN C (1995) Privatization, a matter of incentives: ownership, regulation and information"; Political Economy Review.
(C) This work is licensed under Creative

To Submit Your Article Click Here: Submit Article

DOI: $10.32474 /$ LOJNHC.2018.01.000118

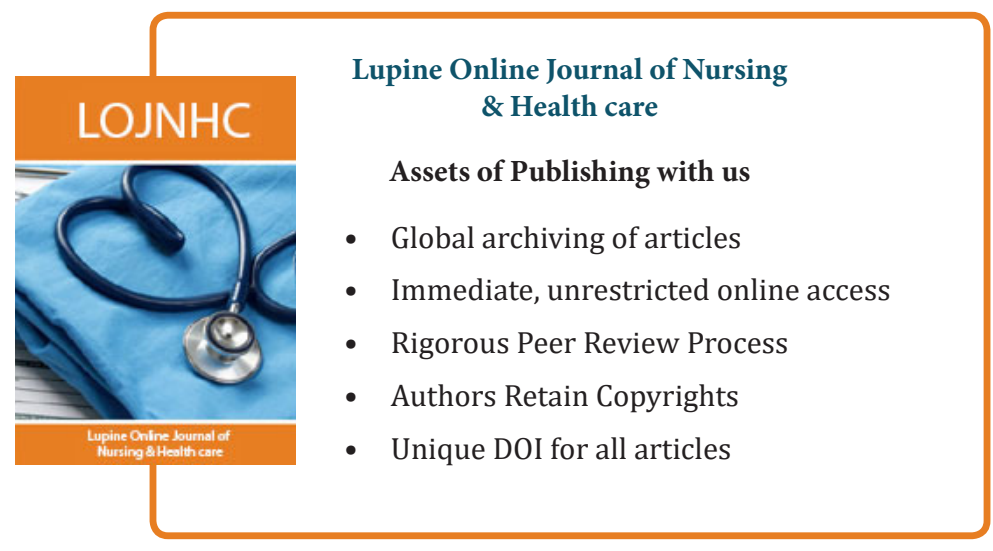

